\title{
Güçlü ve Zayıf Yönleri ile Espor: Yönetici ve Akademisyen Bakış Açısına Dayalı Nitel Bir Çalışma*
}

\author{
Tunahan ASLAN ${ }^{1+}$ (D), Dilşad ÇOKNAZ ${ }^{2}$ \\ ${ }^{1}$ Gazi Üniversitesi, Sağlık Bilimleri Enstitüsü, Ankara \\ ${ }^{2}$ Bolu Abant İzzet Baysal Üniversitesi, Spor Bilimleri Fakültesi, Bolu
}

Orijinal Makale

Gönderi Tarihi: 28.03.2021
Kabul Tarihi: 03.05.2021
DOI:10.25307/jssr.904500

Online Yayın Tarihi: 30.06 .2021

\section{$\ddot{O ̈ z}$}

Gelişen teknoloji ile hayatımıza dahil olan oyun konsolları ve video oyunları 1980’li yıllardan itibaren giderek popülerliğini arttırmıştır. Video oyunlarına gösterilen bu ilgi ve alaka oyun sektörünün gelişimine neden olmuş ve "espor" olarak adlandırdı̆̆ımız kavramın ortaya çıkmasına sebep olmuştur. İzleyici ve katılımcı sayının günden güne artmasının yanı sıra birçok spor kulübü ve şirketin bu alana yatırımlar yapması esporun bir spor türü olup olmadığı hakkındaki tartışmaları yoğunlaştırmıştır. Bu çalışmanın amacı Türkiye'de espor yöneticileri ve spor yönetimi akademisyenlerinin bakış açısına dayalı olarak esporun güçlü ve zayıf yönlerinin incelenmesidir. Araştırma nitel araştırma desenlerinden olgubilim (fenomenoloji) desenine göre tasarlanmış ve veri toplama yöntemi olarak "yarı yapılandırılmış görüşme" yaklaşımı kullanılmıştır. Araştırmada 11 katılımcı yer almış (5 espor yöneticisi 6 spor yönetimi akademisyeni) ve katılımcıların belirlenmesinde ölçüt örneklem kullanılmıştır. Analizler tümevarım yöntemi kullanılarak yapılmış ve bu aşamada Nvivo 10 programından yararlanılmıştır. Esporun güçlü yönleri düşük maliyet, kolay ulaşılabilirlik, kariyer imkânı, ülke tanıtımı, devlet desteği, taraftarlık olgusu, yeni jenerasyon, teknoloji, gelişim potansiyeli, bireysel ve sosyal kazanımlardır. Esporun zayıf yönleri ise tanıtım, hukuki problemler, güvenlik problemleri, sağlık problemleri, tüketicilerin çabuk sıkılması, kariyer süresi, internet altyapısı ve kötü amaçtır. Espor yeni bir alan olmasına karşın yakaladığı büyük gelişme ivmesiyle çoğu geleneksel sporu geride bırakmıştır. Fakat zayıflıkları sebebiyle eksik noktalarının giderilmesine yönelik adımlar atılması gerekmektedir.

Anahtar kelimeler: Espor, Nitel çalışma, Güçlü yönler, Zayıf yönler.

\section{Esports with Its Strengths and Weaknesses: A Qualitative Study Based on the Managerial and Academic Perspective}

\begin{abstract}
From the beginning of 1980s, video games and gaming consoles have grown popularity with advancing new technologies. This attention towards video games has led to improvement of video game industry and emerged "E-sports" concept. Not just growing numbers of viewers, participants and also investments of various companies, sports clubs have blazed up the discussion whether E-sports is a real sports or not. The purpose of this study was to investigate the strengths and weaknesses of eSports in Turkey with point of eSport managers and sport scientists. Qualitative research methods and phenomenology design were used in this research. The data were collected by semi-structured interviews. 11 participants (5 eSport managers and 6 sports scientists) included the research and were selected by the method of criterion sampling. Inductive data analysis was used for data analysis and data was transferred into NVIVO 10 software. The strengths of esports were low cost, accessibility, career opportunity, publicity of country, support of government, fanship, being new generation , technology, developmental potential, and individual and social gains. In addition weaknesses of eSports were determined as recognition, legal problems, cybersecurity problems, health problems, quick boredom of the consumers, career period, internet infrastructure and badly purposes. Despite of eSport's being a new field, it's evolution has gained such a momentum that it surpassed many conventional sports fields. But because of its weaknesses, there needs to be an effort to fix the flawed points of it.
\end{abstract}

Keywords: eSport, Qalitative study, Strengths, Weaknesses.

*Bu araştırma Tunahan Aslan'ın 2019 yılında tamamladığı "Yönetsel ve Akademik Bakış Açısıyla Espor" isimli yayınlanmamış yüksek lisans tezinden üretilmiştir.

$\dagger$ Sorumlu Yazar: Doktora Öğrencisi Tunahan Aslan, E-posta: tunahanaslan@ hotmail.com 


\section{GíRiş}

Son dönemlerde oldukça popüler olan espor geleneksel sporun en güçlü rakiplerinden biri olarak görünmektedir. Kuşkusuz esporun popüler olmasında dijital yerlilerin teknolojiye bağlı yaşam tarzının etkisi büyüktür. Prensky'nin (2001) deyimiyle "dijital yerliler" bilgisayar donanımları ve video oyunları gibi dijital çağın teknolojik araçlarıyla çevrili bir dünyanın içine doğan ve halihazırda bu dünyanın içinde yaşayan bir popülasyonu temsil etmektedir. Bu grup teknolojiye dayalı günlük yaşam pratikleriyle esporun en iyi tüketicileri olarak görünmektedir. Dolayısıyla esporun hızlı yükselişinde lokomotif görevi üstlendiklerini söylemek hiç de yanlış olmayacaktır.

Kendi ekosistemini de oluşturan espor, Covid-19 Pandemisi ile birlikte daha güçlü bir ivme kazanmıştır. 2018 yılında yapılan espor pazar araştırmalarında espor farkındalığı 1 milyar 586,1 milyon kişi, hayran sayısı 165 milyon kişi, espordan elde edilen gelirler 905,6 milyon dolar ve espor organizasyonlarının online platformlarda izlenme süresi ilk 25 oyun için toplam 959,3 milyon saattir (Newzoo, 2018). 2020 yılı için ortaya konan rakamlar dünya çapındaki espor farkındalığının 1 milyar 955,5 milyon kişiye, espor hayranlarının sayısının 222,9 milyona ulaştığını, sponsorluk, reklam, yayın hakları, ürün ve bilet satışı gibi kaynaklardan elde edilen gelirlerin 1 milyar 100,1 milyon dolara çıktığını göstermektedir (Newzoo, 2020). Espor organizasyonlarının canlı olarak yayınlandığı Youtube, Twitch ve Mixer gibi dijital platformlarda en çok izlenen üç oyunun izlenme saatlerine bakıldığında; League of Legends'1n 348,8 milyon, Counter Strike: Global Offensive'in 215 milyon ve DOTA 2'nin 198,9 milyon saat olduğu, sıralamadaki ilk 25 oyunun toplam izlenme süresinin ise 1 milyar 209,6 milyon saat gibi inanılmaz denilebilecek bir süreye ulaştığı anlaşılmaktadır (Newzoo, 2020). 2018 ve 2020 yılları arasında basitçe bir karşılaştırma yapıldı̆̆ında büyümenin ne denli güçlü olduğu rahatlıkla fark edilebilmektedir. Sadece iki yıl gibi kısa bir sürede espor farkındalığının 369,4 milyon kişi arttığı, bu süre içerisinde esporun 57,9 milyon yeni hayran edindiği anlaşılmaktadır. Bu artışların gelirlere ve izlenme saatlerine de yansıdığı, 2018-2020 yılları arasında gelirlerde 194,5 milyon dolar, izlenme süresinde ise 250,3 milyon saatlik 2020 y1lı lehine bir farklılık olduğu görülmektedir.

Espor büyüdükçe espor üzerindeki tartışmalar da hiç azalmadan devam etmektedir. "Espor" veya "Elektronik spor" terimi 1990'lı yıllarda hayatımıza dâhil olmuştur. Terimin ilk kullanıldığı yer, 1999 yılında yapılan eski ve güvenilir bir kaynak olan Online Gamers Association'ın lansmanıdır (Wagner, 2006). Yaklaşık otuz yıllık bir tarihe sahip olmasına rağmen esporun literatürde belirlenmiş tek bir tanımı bulunmamaktadır. Yine de literatürde yapılmış olan çeşitli tanımlar esporu açıklamak için kullanılabilir. Bir tanıma göre espor, siber ortam içerisindeki rekabetçi video veya bilgisayar oyunları, yeni gelişen bir spor dalı olarak tanımlanmaktadır (Jonasson ve Thiborg, 2010). Hamilton (2012) ise elektronik spor veya esporu, "dijital video oyunlarının üst düzey oynanmasına ve gösterimine işaret eder" şeklinde tanımlamıştır (aktaran: Kozachuk ve diğerleri, 2016). Son olarak Keach (2015) espor için "video oyunlarının profesyonelleştirilmesi" şeklinde kısa ve basit bir tanım yapmıştır (aktaran: Özbıçakçı, 2016). Ancak tüm bu tanımlamalara rağmen esporun akademik düzeyde belirli tek bir tanımı yoktur ve esporun eğitim programlarına dahil olduğu günümüzde espor için başlica problemlerden biri budur. Başka bir ifadeyle esporun ne olduğu ya da olmadığı güncel tartışma konularından biri olmaya devam etmektedir. 
Hamari ve Sjöblom (2017) esporun gerçekten bir spor olarak kabul edilip edilemeyeceğine yönelik hala var olan bir dirençten bahsetmektedir. Olimpik eğitim çalışmaları ile bilinen Jim Parry 2019 yılında yazdığ "Espor Spor Değildir”" başlıklı çalışmasında belki de bu konudaki en sert yaklaşımı sergileyerek, esporun sporla benzeşik yönleri tanımlanabilse bile, fiziksel aktiviteden yoksun olması sebebiyle kesinlikle spor olarak nitelendirilemeyeceğini, bilgisayar oyununa sadece oyun denmesi gerektiğini vurgulamaktadır. Jenny, Manning, Keiper ve Olrich (2017) de benzer biçimde oyun, rekabet, kurallar, beceri gerektirme gibi özelliklere sahip olsa da esporu fiziksel etkinlikten ve kurumsallaşmadan oldukça yoksun bir alan olarak görmektedir. Hallmann ve Giel (2018) ise rekreasyon açısından bir tartı̧maya öncülük ederek espor'un spora yakın ancak henüz eşdeğer olmadığını, fiziksel aktiviteleri açısından dart veya satranç gibi alanlar ile karşılaş̧ırılabileceğini ifade etmektedir.

Spor yönetimi ve spor pazarlaması alanında çalışanlar ise esporu bu pedagojik yaklaşımlardan daha farklı şekilde ele almaktadır. Örneğin Funk ve diğerleri (2018) esporu genel fiziksel aktivite ile özdeşleşen spor şeklinde değil, rekabetçi bir sonuca karar vermek için insan vücudunun fiziksel eylemlerini gerektiren modern ve oldukça yapılandırılmış bir faaliyet olarak ele almak gerektiğini ileri sürmektedir. Heere (2018) spor endüstrisinin esporu bir spor olarak benimsemesi sebebi ile akademisyenlerin de esporu, sporlaşmanın bir tezahürü olarak benimsemesi ve endüstri üzerindeki olumlu ve olumsuz etkilerinin incelemesi gerektiğini belirtmektedir. Hallmann ve Giel'in (2018) büyük olasılıkla esporun resmi bir spor olarak kabul edileceği ve hatta en sonunda olimpik programa da dahil edileceği öngörüsü çoktan gerçekleşmiştir. Espor 2022 Asya Oyunlarının resmi dallarından biridir. Tavrı merakla beklenen Uluslararası Olimpiyat Komitesi (UOK) ise espora yönelik mesafesini korumaya devam etmektedir. Sporun en üst yönetsel organının bu tavrı belki de espora yönelik tartışmaların ardındaki itici güç olarak ele alınabilir.

Türkiye açısından espor konusuna döndüğ̈̈müzde, ülkemizde esporun 2000'li yıllarda genellikle Dota ve Counter Strike üzerinden yapılan organizasyonlar ve kafe turnuvaları ile kendini gösterdiğini söylemek mümkündür. League of Legends (LOL) piyasaya çıkana ve Türkiye'de popülerliği artana kadar ise çok büyük bir gelişme göstermemiştir. Bu süre içerisinde World Cyber Games (WCB) elemelerinin ülkemizde gerçekleştirilmiş olması Türkiye'de esporun temellerini atan ana unsur olarak görülebilir. Yine Beşiktaş, Fenerbahçe, Galatasaray ve Bursaspor gibi önde gelen spor kulüplerinin espor takımları kurarak, mücadele etmeye veya yatırım yapmaya başlaması önemli dönüm noktalarındandır. Türkiye'de kulüp bazında yatırımlar 2003 yllında "Dark Passage" espor kulübünün kurulmasıyla başlamıştır (Tarakçı, 2020). Kurumsal anlamda bakıldığında ise 2011 yılında Gençlik ve Spor Bakanlığı altında Türkiye Dijital Oyunlar Federasyonu (TÜDOF) kurulmuştur. Fakat bu federasyon 2013 yılında kapatılmış, ardından Gelişmekte Olan Spor Branşları Federasyonu bünyesinde Dijital Oyunlar As Başkanlığı adı altında tekrar faaliyete geçirilmiştir. Ülkemizdeki ilk resmi espor organizasyonu 2014 yllında League of Legends Şampiyonluk Ligi ve Yükselme Ligi'nin kurulması ile olmuştur (Ntv.com.tr, 2014). Bu ligler bugün hala Türkiye'nin tek profesyonel espor ligleri olma unvanını korumaktadırlar. $\mathrm{Bu}$ liglerde mücadele eden sporculara ise yine 2014 yılından beri Gençlik ve Spor Bakanlığı tarafindan sporcu lisansı verilmektedir. Ayrıca bu oyuncular profesyonel oyuncu olarak kabul edilmektedir. Bu gelişmelerin ve esporun ülkemizdeki popülaritesinin artışından sonra "Türkiye E-spor Federasyonu" adıyla sadece espor için bir federasyon kurulmuştur. 


\section{Araştırmanın Amacı ve Önemi}

Atılan tüm bu adımlara rağmen esporda hem Türkiye, hem dünya genelinde birçok belirsizlik ve eksiklikler bulunmaktadır. Uluslararası bir federasyonu (IeSF) bulunan, birçok ülkede (Güney Kore, Malezya, İngiltere vb.) resmi spor dalı olarak kabul edilen bir alanda halâ esporun bir spor dalı olup olmadığı gibi tartışmaların devam etmesi espor adına en büyük eksikliklerdendir. Ayrıca esporculara sporcu lisansı, sporcu vizesi verilmesi gibi destekler sunulmasına karşın espor liglerinin oyunların yapımcısı olan firmanın sorumluluğunda olması organizasyonun denetiminin, düzenlemelerinin nasıl ve nelere göre yapıldığı gibi soru işaretleri oluşturmaktadır. Yapılan incelemelerde yeni olmasına rağmen çok hızlı gelişen esporun tanımlama, yönetim ve kurumsallaşma ile ilgili sorunları olduğu açıktır. Bu bağlamda esporun araştırılması ve aydınlatılması gereken birçok yönü bulunmaktadır. Türkiye'de yönetsel anlamda konunun uzmanları ve uygulayıcıları ile az sayıda çalışma yapılmış olması da çalışmanın temel gerekçelerinden biridir. Tüm bu bilgiler ışığında mevcut çalışmada Türkiye'de espor yöneticileri ve spor yönetimi akademisyenlerinin bakış açısına dayalı olarak esporun güçlü ve zayıf yönlerinin incelenmesi amaçlanmıştır.

\section{YÖNTEM}

$\mathrm{Bu}$ araştırma betimsel bir araştırma olup, araştırmada nitel araştırma tekniklerinden yararlanılmıştır. Araştırma deseni olgubilim (fenomenoloji) dir. Olgubilim (fenomenoloji) farkında olunan ancak derinlemesine ve ayrıntılı bir anlayışa sahip olunmayan, olaylar, deneyimler, algılar, yönelimler, kavramlar ve durumlar gibi çeşitli biçimlerde şekillenen olgulara odaklı bir desen olup, tamamıla yabancı olunmayan ama aynı zamanda da tam olarak anlamı kavranamayan olguları araştırmayı amaçlayan çalışmalar için uygun bir araştırma zemini oluşturur (Yıldırım ve Şimşek, 2013). Olgubilim deseni araştırma kapsamında yer alan insanlar için araştırılan olgunun kaynağı ve yapısı nedir sorusuna yanıt arayabilen (Patton, 1990) bir yaklaşıma sahiptir. Bu araştırmanın olgubilim deseni ile tasarlanmasının nedeni öncelikle dünyada esporun anlamı üzerine yürütülen tartışmalardan yola çıkarak, kavramın ülkemizde ilgili çevrelerce nasıl ele alındığını anlamak ve yine tüm dünyaya paralel şekilde ülkemizde henüz şekillenen bir alan olması itibarı ile esporun güçlü ve zayıf yönlerine dair derinlemesine bir anlayış ortaya koyabilmektir.

\section{Katılımcilar}

$\mathrm{Bu}$ araştırmadaki katılımcılar amaçlı örneklem yöntemlerinden ölçüt örnekleme ve kolay örnekleme yöntemine göre seçilmiştir. Creswell (1998) olgubilim araştırmalarında ölçüt örneklemenin ideal olduğunu, Patton (1990) ise ölçüt örneklem mantığı ile daha önce belirlenmiş bazı önemli kriterleri karşılayan tüm olguları gözden geçirmek ve araştırmaya odaklanmak gerektiğini söyler. Çalışma konusu güçlü ve zayıf yönleri ile esporun incelemek olduğu için esporu yöneten, espor konusunda akademik çalışmalar üreten yönetici ve akademisyenlerin çalışma için iyi birer veri kaynağı olacağı düşünülmüştür. Bu doğrultuda çalışmada yer alacak katılımcılarda;

-Türkiye'de espor branşında faaliyet göstermiş/gösteren kulüp, takım, lig yöneticisi/temsilcisi olmak,

- Espor alanında akademik çalışmalar yapan spor yönetimi akademisyeni olmak, 
- Türkiye E-spor Federasyonu'nda yönetici/çalışan olmak, ölçütlerinden birine sahip olmasına dikkat edilmiştir.

Devam eden süreçte bu ölçütlere uyanlar arasından kolay örneklem yöntemiyle ulaş1labilenler araştırma kapsamına dâhil edilmiştir. Kolay örneklem araştırmaya hız ve pratiklik kazandırması ve aynı zamanda daha ekonomik olması sebebi ile tercih edilmiştir. 5'i yönetici 6'sı akademisyen olmak üzere araştırmada toplam 11 katılımcı yer almıştır. Araştırmaya katılan yönetici grubunun tamamı erkek katılımcılardan oluşurken akademisyen grubu 4 kadın ve 2 erkek katılımcıdan oluşmaktadır. Araştırmada yer alan katılımcılara ait bilgiler Tablo 1.'de sunulmuştur. Tablo 1.'de katılımcı sütunundaki YK kısaltması yönetici katılımcıları, AK kısaltması ise akademisyen katılımcıları ifade etmektedir. Bu kısaltmalar araştırmanın devam eden bölümlerinde ifadelerin kime ait olduğunu belirtmek için kullanılmıştır.

Tablo 1. Katılımc1 profilleri

\begin{tabular}{cccc}
\hline Kat1lımc1 & Cinsiyet & Eğitim Durumu & Meslek \\
\hline YK1 & E & Lisans & Yönetici \\
YK2 & E & Lisans & Yönetici \\
YK3 & E & Lisans & Yönetici \\
YK4 & E & Lisans & Yönetici \\
YK5 & E & Lisans & Yönetici \\
AK1 & E & Lisansüstü & Akademisyen \\
AK2 & K & Lisansüstü & Akademisyen \\
AK3 & E & Lisansüstü & Akademisyen \\
AK4 & K & Lisansüstü & Akademisyen \\
AK5 & K & Lisansüstü & Akademisyen \\
AK6 & K & Lisansüstü & Akademisyen \\
\hline
\end{tabular}

\section{Araştırma Yayın Etiği}

Bu çalışma Bolu Abant İzzet Baysal Üniversitesi Sosyal Bilimlerde İnsan Araştırmaları Etik Kurulu'nun 27.12.2018 tarihli 2018/11 (Protokol NO. 2018/312) toplantısında Etik onam almiştır.

\section{Verilerin Toplanması}

Veri toplama yöntemi olarak "yarı yapılandırılmış görüşme" yaklaşımı kullanılmıştır. Bu yöntemde görüşmeci katılımcılara konu ve alan ile ilgili olmak üzere önceden hazırlanmış soruları sorabilirken aynı zamanda ek ve ayrıntılı bilgi almak amacıyla ilave sorular sorma özgürlüğüne sahiptir. Bu kapsamda esporun güçlü ve zayıf yönlerini belirleyebilmek için 12 açık uçlu sorudan oluşan bir görüşme formu hazırlanmıştır. Görüşme formu hazırlanırken soruların katılımcılar tarafından anlaşılabilirliğini ölçmek, ilave edilmesi ya da çıkarılması gereken soruları anlamak için bir espor takımının yöneticisi ile deneme görüşmesi yapılmış ve formdaki sorulara son hali verilmiştir.

Katılımcılarla yüz yüze gerçekleştirilen görüşmeler ses kayıt cihazı aracığıyla, katılımcıların onayı dâhilinde kaydedilmiştir. Araştırma esnasında yapılan bütün görüşmeler katılımcılara önceden ulaşılarak araştırmaya katılmak isteyenlerle katılımcıların belirlediği gün, saat ve yerde yüz yüze gerçekleştirilmiştir. Görüşmeler ortalama olarak 20 dakika sürmüştür ve 
araştırma problemi ile ilgili mümkün olduğunca ayrıntılı veri toplanmaya çalışılmıştır. Görüşme sorularında görüşme esnasında herhangi bir kısaltma yapılmamıştır.

\section{Verilerin Analizi}

Verilerin analizinde tümevarım analizi kullanılmıştır. Yıldırım ve Şimşek (2013) tümevarımcı analizi, kodlama yoluyla verilerin altında yatan kavramları ve bu kavramlar arasındaki ilişkileri ortaya çıkarmak şeklinde açıklar. Patton (2002) tümevarım analizini "veriden gelen analiz" olarak tanımlarken, veriler arasındaki örüntüleri, temaları ve kategorileri ortaya çıkarmaktan bahsetmektedir. Kısaca tümevarımcı analiz kodlama ve temalaştırma süreci çerçevesinde ilerleyen bir yapı sergiler. Bu çalışmadan elde edilen verilerin analizinde görüşmeler yolu ile elde edilen veriler, ses kaydından dinlenerek bilgisayar ortamında düz yazı haline getirilmiştir. Metinler dört farklı kişi tarafından

birbirinden bağımsız kodlanmıştır. İlk kodlama sürecinden sonra bu çalışmanın araştırmacıları bir araya gelmiş ve analiz sürecini devam ettirerek temalar oluşturulmuştur. Analizler sırasında NVIVO 10 programı kullanılmıştır.

\section{Geçerlik ve Güvenirlik}

Alan yazın nitel araştırmalarda geçerlik ve güvenirlik yerine kullanılması gereken inandırıcılık, aktarılabilirlik, tutarlık ve teyit edilebilirlik stratejilerinden bahsetmektedir (Yıldırım ve Şimşek, 2013). İnandırıcılık için kullanılabilecek yöntemler uzun süreli etkileşim, derin odaklı veri toplama, çeşitleme, uzman incelemesi ve katılımcı teyididir. $\mathrm{Bu}$ çalışmadaki araştırmacılardan birinin 2010 yılından beri amatör olarak espor ile ilgilenmesi ve alanı yakından takip etmesi uzun süreli etkileşim koşulunu sağlamaktadır. Derin odaklı veri toplama koşulu için araştırmacılar elde ettikleri sonuçları birbiri ile sürekli karşılaştırarak yorumlayıp, bulgular arasında örüntüleri ortaya koymaya çalışarak sağlamıştır. Akademisyen ve yöneticiler olmak üzere iki farklı birimden elde edilen veriler veri çeşitlemesini, analiz aşamasında dört farklı kişinin analiz yapması analiz çeşitlemesini sağlamıştır. Araştırmacılar en başından sonuna kadar tüm süreçlerde gerek yüz yüze toplantılar yaparak gerekse farklı iletişim yöntemlerini kullanarak her aşamada fikir alışverişinde bulunmuştur.

Okuyucunun herhangi bir yönlendirilme yapılmaksızın, yansız değerlendirip kavramlarla ilişkinin nasıl kurulduğunun gözlemlemesi adına verilerin kısmen ham ve en yalın hali ile sunulmasına dikkat edilerek ayrıntılı betimleme ile araştırmanın aktarılabilirliği güçlendirilmiştir. Yine amaçlı örneklem yöntemlerinden ölçüt örnekleme ve kolay örnekleme birlikte kullanılarak araştırmaya dahil edilen veri kaynaklarının, bu farklılığı yansıtacak biçimde seçilmesine dikkat edilmiş ve aktarılabilirlik sağlanmıştır. Araştırmada esporun farklı yönleri ile incelenmesi amaçlandığı için bu konu hakkında bilgi sahibi olan, esporu yöneten, espor konusunda akademik çalışmalar üreten yönetici ve akademisyenlerin çalışma için iyi birer veri kaynağı olacağı düşünülmüştür.

Araştırmada tutarlığın sağlanabilmesi için katılımcılara verilerin bilimsel amaçla toplandığ 1 ve elde edilen kayıtların gizli kalacağı beyan edilmiştir. Böylece katılımcıların samimi ve güvenilir bir şekilde cevap verebilmeleri sağlanmıştır. Araştırma için Bolu Abant İzzet Baysal Üniversitesi İnsan Araştırmaları Etik Kurulu'ndan izin alınmıştır (Protokol No: 2018/312). Ayrıca kodlayıcılar arası tutarlık hesaplanmıştır. Miles ve Huberman'ın (1994) "Görüş Birliği / (Görüş Birliği + Görüş Ayrıllı̆̆1)" formülüne göre yapılan hesaplamalar 
sonucu kodlayıcılar arasındaki tutarlılık \%71 olarak tespit edilmiştir. Son olarak teyit edilebilirlik koşulunu sağlamak üzere araştırmacıların elde ettiği ham veriler, yapılan kodlamalar daha sonra incelenebilmesi adına muhafaza edilmektedir.

\section{BULGULAR}

Araştırma bulguları iki ana başlık altında sunulmuştur. İlk bölümde olumlu yönler olarak da ifade edilebilecek esporun güçlü yönleri yer almaktadır. İkinci bölümde ise olumsuzlukları ifade eden zayıflıklar sunulmuştur.

\section{Yönetici ve Akademisyenlerin Bakış Açısına Göre Esporun Güçlü Yönleri}

Esporun güçlü yönleri ile ilgili olarak spor yöneticileri ve spor yönetimi akademisyenlerinin ifadelerine dayalı ortaya çıkan tüm temalar Şekil 1.'de sunulmuştur. Katılımcıların bakış açılarına dayalı olarak esporun; düşük maliyet, kolay ulaşılabilirlik, kariyer imkânı, ülke tanıtımı, devlet desteği, taraftarlık olgusu, yeni jenerasyon, teknoloji, gelişim potansiyeli, bireysel ve sosyal kazanımlar gibi güçlü yönlere sahip olduğu tespit edilmiştir.

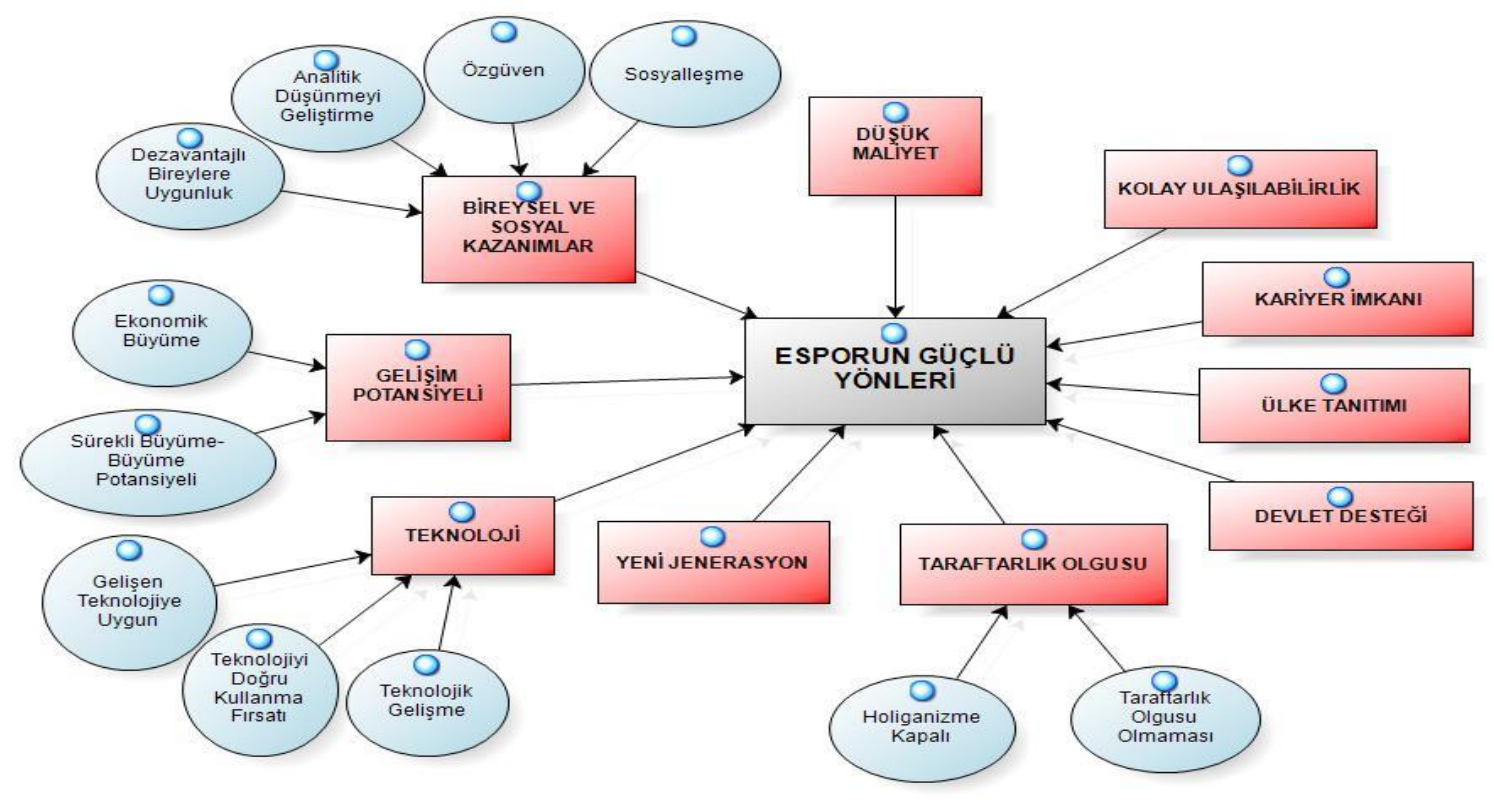

Şekil 1. Akademisyen ve yöneticilere göre esporun güçlü yönleri

\section{Düşük Maliyet}

Araştırmada yer alan katılımcılardan YK-2'ye göre espor maliyeti bakımından oldukça ucuz bir etkinlik alanıdır. Katılımcı "diğer aktivitelerle kıyasladı̆̆ımız zaman oyunun her zaman ucuz olması" ifadesi ile esporun ekonomikliğine vurgu yapmakta ve esporu maliyetleri anlamında bireyi zorlamayan, kişiye yüklenen maliyet açısında daha makul bir etkinlik olarak değerlendirmektedir. 


\section{Kolay Ulaşılabilirlik}

Katılımc1 AK-5 ve YK-4'e göre esporun güçlü yönlerinden biri de kolay ulaşılabilir olmasıdır. AK-5 "her zaman ulaşılabilir olması açısından elektronik spor avantajlı” derken zaman açısından kolay ulaşılabilirliğe dikkat çekmektedir. YK-4 ise "Futbol oynayacaksınız mesela 11 kişi bulmanız lazım ya da basit halı saha maçı 6’ya 6 kişi ... Esporda squad diye tabir ettiğimiz 5 kişi, 4 kişi, 3 kişi ya da duo dediğimiz 2 kişi mevcuttur. Dolayısıly 10 kişinin ya da 6 kişinin organize olmasından, 2 kişinin organize olması daha hızl ve kolay olduğu için diğer sporlara göre daha kolay bir takım oluşmaktadır" ifadesi ile zamansal ve organizasyonel kolaylıkları güçlü yön olarak değerlendirmiştir.

\section{Kariyer İmkânı}

Hızla büyüyen bir ekosisteme sahip esporun, yeni iş fursatları yaratma potansiyeli güçlü yönlerinden biridir. Katılımcılardan AK-3 "birçok kişiye hem yönetim anlamında hem antrenörlük anlamında farklı iş imkânları sağlayacağını, aynı zamanda sporcu olarak da bireylere bir iş ortamı yaratacağı fikrine sahibim" ifadesinde bu kariyer imkanlarının sporculuk, antrenörlük ve yöneticilik alanlarında olabileceği ifade edilirken, YK-2 "Artık kariyerleri sadece Türkiye'de veyahut bulundukları şehir veya kasabada değil dünyanın her yerinde devam ettirebilme imkânı sağllyor espor" ifadesinde kariyer imkanlarının evrenselleştiği anlaşılmaktadır.

\section{Ülke Tanıtımına Katkısı}

Katılımcılardan YK-2'nin, "Ülkeyi tanıtmak, ülkenin gençliğini tanıtmak için çok değerli” ifadesi, esporun diğer sporlara atfedilen tanıtım ve reklam gibi güçlü bir yönünün olduğunu ortaya koymaktadır.

\section{Devlet Desteği}

Araştırmadaki katılımcılardan YK-3 ülkemizde espora verilen devlet desteğinin güçlü bir yön olduğunu şu ifadesiyle açıklamaktadır: "Geçen Kasım ayında, yurt dışında Uluslararası Espor Federasyonunun bir toplantısı vardl, oraya katıldık. Oradaki birçok espor federasyonu veya kuruluşu dernek adı altında, devletten bir destek görmemiş, devlet kabul etmemişti. Ama Türkiye'de devletin kabul ettiği bir federasyon olmuş. Devlet sayesinde, devlet imkânlartyla kurulmuş bir federasyon var. Bence bu önemli bir nokta”.

\section{Taraftarlık Olgusu}

Araştırtmada günümüzde neredeyse tüm sporların mustarip olduğu şiddet, holiganizm gibi kavramların esporda olmaması esporun güçlü yönlerinden biri olarak öne çıkarılmıştır. Bu durum YK-5'in “Esporda ben bu fanatikliğin çok fazla olmadığını düşünüyorum.", "Fakat esporun bir güzel tarafı spor algısına böyle bir etki olması. Hani insanlar aslında bir oyun izlediklerini ve bu oyunun amacının ĕglence olduğunu daha rahat fark edebiliyorlar" şeklindeki ifadesinde görülmektedir.

\section{Yeni Jenerasyon}

Esporun güçlü yönlerinden biri yeni jenerasyona uygun, yeni jenerasyon bir etkinlik alanı olmasıdır. "Günümüzde artık çocuklar sokakta oynamıyorlar. Bunlar büyüdüklerinde de bugün maç izleyerek, futbol maçı izleyerek zaman geçiren kitle kalmayacak artık. Bunlar espor müsabakaları izleyerek zaman geçiren kitleye dönüşüyor” tespiti ile YK-1; "Espor 
şöyle inanılmaz, yeni nesil z kuşă̆g diyelim, .......... şu an yetişen çocuklarımıza bakttğımız zaman 3 yaşında Ipad'lerle, Iphone'larla oyun oynayarak, dolaylsiyla da motor becerileri de çok yüksek seviyede oluyor bu arkadaşlarımızın, kardeşlerimizin, böyle bir jenerasyonun böyle bir insanlı̆̆ı buraya gittiği bir noktada esporun gelişmemesi mümkün değil." tespiti ile YK-3 esporun gelecek nesillerin izleyeceği ve yapacağı ve bu gidişattan kaçınmanın mümkün olmadığını bir alan olduğunu anlatmaktadır. Yine AK-4 "Geleneksel sporlara, ona doğan jenerasyonlar zaten çok da fazla yönelmiyorlar" ifadesi ile günümüz dünyasında yetişen yeni jenerasyonların espordan önceki spor dallarını pek takip etmediklerini, yeni nesil arasında yaygın olanın espor olduğunu vurgulamış ve bunu da espor açısından bir avantaj olarak değerlendirmiştir.

Ayrıca YK-2 ve AK-3; "Bizim gibi genç popülasyonu olan bir ülke için ayrıca değerli buluyorum" ve "Mevcut olarak ülkemiz adına önemli bir firsat var çünkü genç bir nüfusa sahibiz. Genç nüfus içerisinde oyun oynama alışkanlı̆ğ yüksek" şeklindeki ifadeleri ile yeni jenerasyon bağlamında ülkemize özgü bir güçlü yönden bahsetmişlerdir.

\section{Teknoloji}

Her geçen gün biraz daha hayatın odağı haline gelen teknolojinin esporun insan yaşamına girmesini kolaylaştırdığı ve kolaylaştıracağı, daha hızlı yayılmasını sağlayacağı ve esporun bu teknolojilere uyum sağlama konusundaki gücü katılımcıların;

“...teknoloji çok hızlı ilerliyor. Dolayısıyla esporun ileride çok daha yaygın olabileceğini, bir aileyi, iş̧e çekirdek aileyi anne, baba, çocuklar, dört kişi olarak farz edersek oyun oynamayan bir kimsenin on sene içerisinde kalmayacağını değerlendiriyorum." (AK-1)

"Teknoloji linear değil, iki üzeri iki şeklinde gelişiyor sürekli. Yarınki teknolojiyi bugünden yakalayamıyoruz çok hızl gelişiyor ve bu hızl gelişen teknolojinin bir ürünü aslinda espor, bizim için ve onun da bu kadar huzl gelişmesini bekliyoruz." (AK-4),

"hem akademik anlamda hem de özel hayatlarındaki teknoloji zaten hayatımızın her alanın sarmış, bizi sarmış durumda, bunu doğru şekilde kullanmak adına iyi bir araç olduğunu düşünüyorum" (AK-6),

"Dünyada teknolojinin çok çok huzl ilerlemesi ve bu teknolojiyi yakalayabilecek sayll alanlardan biri espor. Yani sadece spor olarak bakmiyorum genel olarak bütün sektörlere baktı̆ı̆ zaman dünyadaki teknolojik gelişme hızını yakalayabilecek sayll alanlardan biri espor" (YK-5) ifadelerinde şekillenmiştir.

\section{Gelişim Potansiyeli}

Katılımcılar YK-1, YK-3, AK-4 ve YK-4 espor alanının sürekli büyüyen bir ekonomiye ve ivmeye sahip olduğunu belirtmişlerdir. Katılımcıların değerlendirmeleri analiz edildiğinde "sürekli büyüme-büyüme potansiyeli", "ekonomik büyüme" kodları ile "gelişim potansiyeli" temas1 oluşturulmuştur. Kat1lımc1lardan YK-1'in "Sektörde önümüzdeki 10 yllda tahmin bile edemeyeceğimiz kadar futbol veya işte Superbowl'dan bile daha büyük bir yerlere gelecek"; YK-3'ün "espor zaten şu anda her sene \%30-\%40'llk olarak büyüyor hem izleyici hem ekonomik boyut olarak söylüyorum bunu”; YK-4'ün: “... 50 sene önce futbola baklş açısı nasılsa bugün espora bakış açısının o şekilde olduğunu düşünüyorum. Bundan 20 sene sonra esporun futbolun yerini alabilecek kapasitede bir spor ve ekosistem olacağını düşünmekteyim” ve AK-4'ün "Bence espor yaklaşılk 10 sene içerisinde geleneksel sporlar 
hani piyasadan silecek gibi büyük bir terim kullanmayayım da çok çok önüne geçecek piyasanın" ifadeleri gelişim potansiyelini açıklayan ifadelerdir.

\section{Bireysel ve Sosyal Kazanımlar}

Güçlü yönlerden sonuncusu "bireysel ve sosyal kazanımlar" esporun kişilerin sosyalleşmesine katkıda bulunması, özgüven ve analitik düşünme becerisini geliştirmesi ayrıca dezavantajlı bireyler için de uygun olması ile ilgilidir. Katılımcıların konuyla ilgili ifadelerine bakıldığında YK-2'nin dezavantajlı bireylerden “Espor şöyle bir kere dünyalar birbirine bağllyor. Yani siz önünüzdeki bilgisayar veya oyunu icra ettiğiniz konsol veya her neyse platform üzerinden dünyaya bağlanıyorsunuz. Dünyada birçok arkadaşınız olabiliyor, hiç yüz yüze görüşmediğiniz sadece sesini duyduğunuz veya yüzünü de görse yan yana bulunmadığınız" şeklindeki ifadesinde, özgüvenden ise "Gençlerimizin kendine bu konuda özgüvenini pekiştiriyor” ifadesinde bahsettiği görülmektedir. Yine AK-5 “En büyük yarattı̆̆ avantajl ve yarattığ firsat dezavantajlı bireyler yani yardıma muhtaç, evde bakıma muhtaç, eve kapalı kalmış engelli çocuklar işse ne bileyim herhangi bir ĕgitim-öğretim sportif anlamda bir ĕgitim-öğretime maddi durumu yetmeyen çocuklar bu tür sanal ortamlarda her zaman bir firsat bulabiliyor" şeklindeki ifadesinde dezavantajlı bireyler açısından esporun avantajlarına dikkat çekmektedir. Son olarak AK-6 "espor bireylerin bilişsel anlamda, farkındalık anlamında, analitik düşünme anlamında özellikle analitik anlamda çok geliştiren bir aktiviteler bütünü” ifadesi ile analitik düşünme kazanımına vurgu yapmaktadır.

\section{Yönetici ve Akademisyenlerin Bakış Açısına Göre Esporun Zayıf Yönleri}

Çalışmada esporun olumsuz tarafları olarak da nitelendirilebilecek ve katılımcı ifadelerinin analizi sonucu belirlenen zayıf yönler Şekil 2.'de sunulmuştur. Bu zayıf yönler; tanıtım, hukuki problemler, güvenlik problemleri, sağlı problemleri, tüketicilerin çabuk sıkılması, kariyer süresi, internet altyapısı, regülasyon eksikliği ve kötü amaçtır.

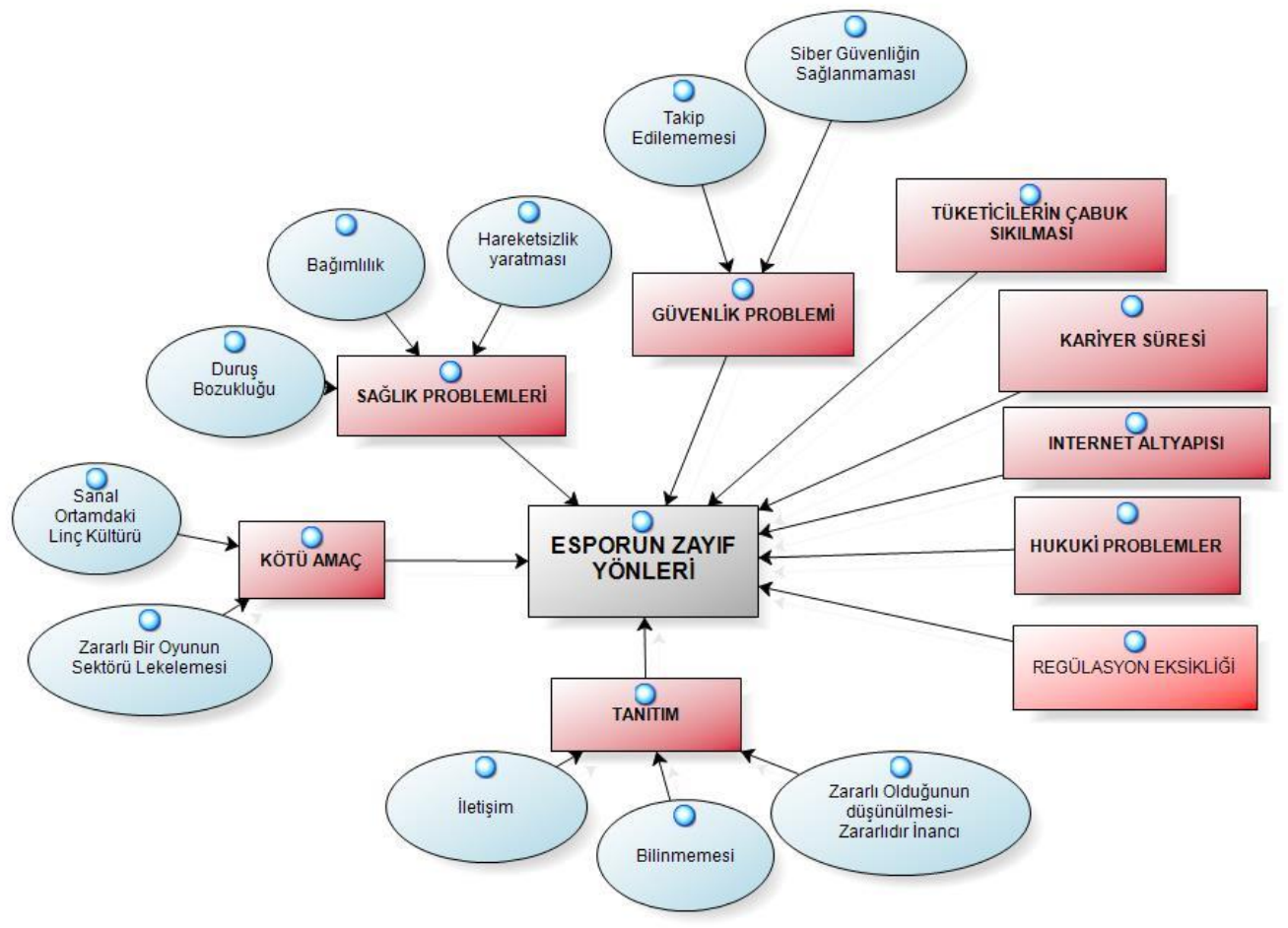

Şekil 2. Akademisyen ve yöneticilere göre esporun zayıf yönleri 


\section{Tanitım}

Katılımcıların "Bence en zayıf yanı esporun bilinmemesi, ... en büyük sıkıntı yanlış bir şey olduğunu düşünüyor insanlar. Dezavantajının o olduğunu düşünüyorum”(AK-1); "Esporun şöyle bir zaylf yanı diyebiliriz. Burada şeyi çok doğru anlatmak gerekiyor insanlara biliyorsun ebeveynler, espor yapan arkadaşlarımızın genellikle yaş ortalaması 15-22 diyelim bu aralığa genç bir kitlesi var espor oyuncularının. Dolayısıyla hala ebeveynin kontrolünde olan kişiler oynuyor bu oyunu ve ebeveynlerin haklı olarak bazı kayglları oluyor. Bilgisayar oyunu olarak gözüktüğü için espor bilgisayar oyunlarına zaman harcanması, kişisel gelişimi etkilediği düşünülüyor."(YK-3) şeklindeki ifadeleri aileler ile gerekli iletişimlerin kurulamamasının, espor kavramının ve kendisinin tam olarak bilinmemesinin yanı sıra zararlı olduğuna yönelik inançların esporun tanıtıma dair zayıf bir yönü olduğunu ortaya koymaktadır.

\section{Hukuki Problemler}

Katılımcı YK-1'in "oyun şirketlerine ait olması bunlar çözülemez yani çözülecek zaman içinde ama böyle tam anlamıyla anonimleşmeyecek." ifadesine dayalı olarak hukuki problemler esporun zayıf yönlerinden biri olarak değerlendirilmiştir.

\section{Regülasyon Eksikliği}

Katılımc AK-4 "esporun şu anda ne ulusal ne de uluslararası belirli bir regülasyonu yok" ifadesi ile esporun zayıf yönü olarak düzenleme eksiklikleri üzerinde durmuştur. Katılımcının bu değerlendirmesi çerçevesinde "regülasyon eksikliği”" teması tanımlanmıştır.

\section{Güvenlik Problemi}

Araştırmada AK-2 esporun zayıf yönlerinden bahsederken "Zayıf yönleri..... takip edilememesi, siber güvenliğin sağlanamaması" ifadelerini kullanmıştır. Katılımcının ifadeleri analiz edildiğinde ortaya "takip edilememesi", "siber güvenliğin sağlanmaması" kodları ile "güvenlik problemleri” teması oluşturulmuştur.

\section{Să̆lık Problemleri}

Katılımcılar YK-1, YK-2, AK-3, AK-5, YK-4 ve AK-6 yaptıkları değerlendirmelerde esporun oyun platformları karşısında yapılmak zorunda oluşunun bireyleri hareketsiz bir yaşama itme olasılığından bahsetmişlerdir. Ayrıca oyun oynama alışkanlığının bir bağımlılığa dönme tehlikesi üzerinde dururlarken, fiziksel olarak duruş bozuklukları gibi sağlık sorunları oluşturabileceğini belirtmişlerdir. Katılımcı görüşlerine dayalı olarak sağlık problemleri esporun zayıf yanlarından biri olarak değerlendirilmiştir. Bu zayıf yön ile ilgili katılımcı ifadelerine bakıldığında katılımcı YK-1'in düşüncesini "kendini disipline edemeyen insanları bilgisayarın başına bağımlı bir hayata sürükleyebilir belki.”; YK-2'nin “bir bă̆ımlılı̆̆a dönüşebilir, oyun bağımlılıklarl vs. gibi şeyler de var. ”; AK-3'ün “Ĕger doğru yönetilmezse, yani bu bireylere müsabakalar esnasında ya da bunun dişında antrenman programlar içerisinde bir egzersiz programı, aktif olarak katılabilecekleri bir egzersiz programı ve oluşturulmazsa önemli sorunlara yol açabilir.”; AK-5'in “burada bir farklılık öne çıkıyor. Elektronik sporu düşündüğ̈̈̈mde sadece bilgisayar oyunlart ya da kişilerin çok uzun sürelerle bilgisayar başında ekran karşısında sabit kalmaları evet bir bozukluk. Yani duruş bozukluğu ortaya çıkabilir, burada beslenme bozukluğu ortaya çıkabilir. İşte internet hastanelerinin kurulması, Hollanda'da bunların en büyük göstergesi maalesef. İnsanların su bile içmeyerek 
sadece klavye ve bilgisayarla haşır neşir olmast saatlerce, bunlar hep sakncalı diyebileceğimiz şeyler."; YK-4'ün "Şimdi burada hep en çok eleştiri ... teknoloji bağımlılı̆̆ ve hareket etmeme." ve AK-6'nın "Şimdi o açıldan baktığımızda da tabi biraz daha fiziksel aktiviteden uzaklaşma söz konusu olabiliyor. Daha durağan ve işte bilgisayar başında uzun saatler geçirilmesi dolayısıyla hareketsizlikle ortaya çıkan problemler yaşanabilir." ifadeleri ile açıklamışlardır.

\section{Tüketicilerin Çabuk Sıkılması}

Diğer bir zayıf yön olarak tüketim alışkanlıklarının bir sonucu olarak esporun popülaritesini kaybetme ihtimali katılımcının verdiği "tüketim çă̆ının getirdiği bizdeki bu sıkllganlı esporu da tehdit eder mi hani hep böyle insanlar yeni yeni oyunlara eğilir ve bir süre sonra acaba bunun bir spor olur mu olmaz mı soruların getirebilir. (YK-2)" ifadesi ile ortaya konmuştur.

\section{Kariyer Süresi}

Profesyonel espor ile uğraşan sporcuların geleneksel sporlardaki sporcular ile karşılaştıııldığında çok daha erken yaşta emekliye ayrılması, esporun zayıf ve eksik bir yönü olarak üzerinde durulan konular arasında yer almıştır. Katılımcılardan AK-2 bu zayıflığı "2223 yaşında birakiyorlar esporculuğu. En zaylf yanlarından biri o." şeklinde ifade etmiştir. YK-5 ise "Şöyle bir zaylf yan görülebilir. Nasll diyeyim, esporcular genç yaşta, çünkü refleksler ve oyuncuların hani beyinsel, zihinsel gelişimi, fiziksel gelişimi en hizll 16-24 yaş aralarında oluyor. Tabi ki en yaşlı oyuncu 27 yaşında şu an dünyada ama bu uç bir örnek." ve "bütün takım harll harıl bir daha yeni oyuna alş̧maya çalş̧lyorlar, onun hakkinda strateji üretmeye çallşlyorlar. Bu aslında bizim oyuncularımızın dünyadaki bütün espor oyuncularının çabuk "burnout" diye bir tabir vardır çabuk kafalarının yanmasına neden oluyor. Hani kariyerlerinin kisa kalmasindaki bir şey bu bence, ben böyle düşünüyorum." şeklindeki ifadesi ile yaşa bağı bir takım beceri kayıplarının esporda kariyeri kısalttı̆̆ını dile getirmiştir.

\section{Internet Altyapıst}

Esporun yapısal olarak internete bağımlılı̆̆ zayıf yönlerden bir diğeridir. AK-2 kodlu katılımcı bu durumu şu şekilde açıklamaktadır: "en zayıf yönü mesela müsabaka esnasinda bulunduğunuz ülkenin internet săglayıcısının size yeteri kadar hizmet edememesi."

\section{Kötü Amaç}

Son olarak zayıf yönleri ifade eden "kötü amaç" teması, "sanal ortamdaki linç kültürü" ve "zararlı bir oyunun sektörü lekelemesi" kodları ile belirginleşmiştir. Bu konuda kat1lımc1lardan YK-3 "esporun bence en büyük sikintısl ... bir oyun bütün sektörü lekeleyebiliyor." ifadesinde zararlı oyunlara dikkat çektiği görülmektedir. YK-5 ise "kötü bir oyunla beraber bir linç kültürü var sanal ortamda" ifadesi ile sosyal medyada olduğu gibi bu alanda da linçe yönelik söylemlerin espor açısından zayıflık yarattığını ve geleceğini tehdit eden bir yön olduğunu belirtmiştir. 


\section{TARTIŞMA VE SONUÇ}

$\mathrm{Bu}$ araştırmada spor yönetimi akademisyenlerinin ve espor yöneticilerinin bakış açısına dayalı olarak esporun güçlü ve zayıf yönleri incelenmeye çalışılmıştır. Tablo 2 akademisyen ve yöneticilerin bakış açısına dayalı belirlenen güçlü ve zayıf yönlerin bir özetini içermektedir.

Tablo 2. Esporun güçlü ve zayıf yönleri

\begin{tabular}{ll}
\hline ESPORUN GÜÇLÜ YÖNLERI & ESPORUN ZAYIF YÖNLERI \\
\hline Düşük Maliyet & Tanıtım \\
Kolay Ulaşılabilirlik & Hukuki Problemler \\
Kariyer İmkânı & Güvenlik Problemi \\
Ülke Tanıtımına Katkı & Sağlık Problemleri \\
Devlet Desteği & Tüketicilerin Çabuk Sıkılması \\
Taraftarlık Olgusu & Kariyer Süresi \\
Yeni Jenerasyon & İnternet Alt Yapısı \\
Teknoloji & Kötü Amaç \\
Gelişim Potansiyeli & Regülasyon Eksikliği \\
Bireysel ve Sosyal Kazanımlar & \\
\hline
\end{tabular}

Katılımcıların bakış açısına dayalı belirlenen güçlü yönler düşük maliyet, kolay ulaşılabilirlik, kariyer imkanı, ülke tanıtımına katkı, devlet desteği, taraftarlık olgusu, yeni jenerasyon, teknoloji, gelişim potansiyeli, bireysel ve sosyal kazanımlardır. Bugün esporun güçlü yönlerini tartışırken Covid-19 ile birlikte bireylerin yaşam pratikleri ve tüketim biçimlerinin oldukça büyük bir değişime uğradığını ve şüphesiz ki bu değişimin espor gibi alanların yükselişini hızlandırdığını göz önünde bulundurmak gerekebilir. Ancak tüm ivmeyi son bir yılda yaşananlara bağlamak espor gibi alanlarda teknoloji ve dijitalleşmenin etkisini yok saymak anlamına da gelebilir. Son yıllarda pek çok hizmete zaten hiç dışarı çıkmadan erişim sağlanabilen bir ortamda kuşkusuz esporun da en güçlü yönlerinden biri katılımcıların üzerinde durduğu kolay ulaşılabilirlik ve buna bağlı olarak düşünülebilecek düşük maliyet olmuştur. Geleneksel spor dalları olarak tabir edilen sporların herhangi bir kişi tarafından yapılması için öncellikle ilgili sporla alakalı ekipmanlara sahip olması gerekmektedir. Ekipman gereksinimi bu sporu yapmak isteyen birey için ekonomik bir yük oluşturur. Bu bağlamda katılımcılar video oyunlarının diğer spor dalları için gerekli olan ekipmanlardan daha uygun fiyatlı olmasını bireylerin espora yönlenmesini sağlayacak bir etken olarak değerlendirmiştir. Bakıldığı zaman espora konu olan oyunların çoğunun ücretsiz (Dota2, League of Legends, Heartstone, Counter Strike: Global Offensive vb.) ve bu oyunlar için gerekli olan oyun konsollarının dünya genelindeki fiyatlarının uygun oluşu esporun diğer spor dallarına göre daha fazla tercih edilmesini sağlayacak nedenler olarak düşünülebilir. Ayrıca geleneksel spor dallarını yapabilmek için gerekli ekipmanların dışında bir de o spor dalı ile ilgili diğer katılımcılara ve uygulama alanına (saha, kort vb.) sahip olmak gerekmekte ve tüm bunlara ulaşım zaman zaman kolay olmamaktadır. Oysa katılımcıların da dikkat çektiği gibi espor kolay ulaşılabilen, oyun konsolu, sabit bir internet bağlantısı ve ilgili oyuna sahip olunması dışında hemen hemen hiçbir şey istenmeyen bir özelliğe sahiptir. Ayrıca bu oyunlar günün herhangi bir saatinde oynanabilen, hava şartlarından bağımsız olarak yapılabilen ve katılımcı aramaya gerek kalınmayan, sadece oyunu oynamak için bekleyen kişilerle eşleştirmenin yeterli olduğu uygulamalardır. Bu durum diğer spor dalları ile kıyaslandığında esporun tercih edilmesini sağlayabilecek güçlü yönlerden biri olarak 
değerlendirilebilir. Katılımcıların esporun güçlü yanı olarak gördükleri kariyer imkanlarından bahseden Türsen (2017) bu imkanlarla ilgili olarak "espor'da kariyer yapmak isteyenler diğer sporlarda olduğu gibi antrenör de olabiliyorlar. As takım beşer kişiden oluşuyor. Yedekler, antrenörler ile beraber bir espor takımındakilerin saylsl 10'u geçiyor. Tüm dünyada yeni gelişen bir spor dalı olmasina rağmen espor'da kariyer yapmak isteyenlerin saylsı giderek artiyor. Türkiye'de yaklaşık 3.300 espor lisanslı oyuncu bulunuyor. ABD'de bazı üniversiteler espor bursları veriyor" beyanı ile esporun iş imkanları açısından sahip olduğu potansiyeli vurgulamıştır.

Katılımcılar uygun yatırımlar ve uygulamalar ile esporda elde edilecek başarıların ülkemiz adına bir tanıtım firsatı yarattığından bahsetmiştir. Türkiye 2016 yılında Counter Strike: Global Offensive dünya şampiyonasında birinci olmuştur (Ntv.com.tr, 2016). Ayrıca "Broken Blade" adıyla bilinen Sergen Çelik 2018 yılında League of Legends arenasının önemli ekiplerinden TeamSoloMid'e transfer olarak (Demirkol, 2018) bireysel anlamda gelecek vadettiğimizi göstermiştir. Bu gelişmeler dikkate alındığında ülkemizin espor alanında başarılı olma ihtimalinin yüksek olduğu ve bunun ülkemizin tanıtımı için bir firsat oluşturduğu görülmektedir. Türkiye olarak sahip olduğumuz bu avantajın yanı sıra katılımcılardan YK-4'ün de bahsettiği gibi ülkemizde espora verilen devlet desteğinin diğer ülkelerle kıyaslandı̆̆ı zaman güçlü bir yön olarak öne çıktı̆̆ı görülmektedir.

Günümüzde profesyonel düzeydeki geleneksel sporların en sorunlu taraflarından biri holiganizmdir. Kötü davranışları ile bilinen holigan taraftarlar bir spor etkinliğinde istenmeyen olayların yaşanmasına neden olurlar. Katılımcıların ifade ettiğine göre esporda böyle bir durum yoktur çünkü espor taraftarı takımını desteklerken, izlediği aktivitenin eğlence amaçlı olduğunu unutmaz ve şiddet içerikli davranışlardan uzak duran bir yapıya sahiptir. Araştırmadaki katılımcılar takipçi kitlesi ile alakalı olarak yeni neslin geleneksel spordan ziyade esporu takip ettiğini ve bu sebeple her geçen gün esporun takipçi, izleyici ve uygulayıcı kişi sayısının artacağına dikkat çekmiş̧lerdir. Konu hakkında Uluslararası Espor Federasyonu Genel Sekreteri Alex Lim, "Bir jenerasyon top oynayarak büyümüştü, diğerleri ise oyunlar içerisinden tercih yaparak büyüyor. Bir dizi şey gibi spor da dijital kültürün içerisinde yeniden tanımlanıyor" (Aktaran: Akgöl, 2018) ifadelerini kullanarak gençler arasında esporun yaygınlaşacağına işaret etmiştir.

Araştırmada katılımcıların üzerinde durduğu güçlü yönlerden bir diğeri espor ve teknoloji arasındaki uyumdur. Aslında geleneksel spor da bu teknolojik gelişmelere sıcak bakmakta, VAR teknolojisi gibi uygulamalar sporun teknolojiden uzak kalamadığını ve uyum sağlamaya çalıştı̆̆ını göstermektedir. Fakat espor teknolojiye dayalı ortaya çıkan bir spor dalı olarak bu konuda açık ara öndedir. Espor camiasının köklü kulüplerinden olan Cloud9 ve teknolojinin önde gelen şirketlerinden Microsoft'un yaptığı teknoloji anlaşması bunun en önemli göstergelerindendir. Microsoft Spor Teknolojileri Direktörü Mike Downey'in bu konudaki açıklamasi; "Bunun için Microsoft'a ait bir takım ticari ve tüketici hedefli ürün ve servisleri kullanacağız. Cloud9 ile birlikte çalışarak, daha etkili antrenman yapmalarını ve kazanmak için en iyi stratejilere karar vermelerini sağlayacak araçlar üreteceğiz" şeklinde olmuştur (aktaran: Karahan, 2019). 
Espor ortaya çıktığı günden bugüne sürekli hem ekonomik bakımdan hem de izleyici kitlesi bakımından gelişen bir yapıya sahiptir. Son yıllarda kazandığ popülerlik önemli marka, takım ve bireysel yatırımcıların ilgisini çekmektedir. Özenç ve Tınmazlar (2019)'a göre herhangi bir ürün ortaya çıktıktan sonra kendi piyasasını yaratır ve o ürüne ve piyasaya yapılacak yatırımlar artar çünkü popüler olan karlıdır ve kar, para kazanmak isteyenlerin, bilhassa da hali hazırda parası olan yatırımcıların dikkatini çeker. Bu açıdan bakıldığında espor sahip olduğu ekonomik değer ve potansiyel ile kendi içerisinde gelişimi için bir firsat barındırmakta, bu da onu güçlü kılmaktadır.

Esporun güçlü yönlerinden sonuncusu bireysel ve sosyal kazanımlar olarak şekillenmiştir. Video oyunları insan hayatına girdiği günden bugüne asosyal kimlik oluşturma ya da genel olarak zararlı bir aktivite olarak eleştirilmektedir. Fakat araştırmada yer alan katılımcılar esporun özellikle dezavantajlı gruplar için değerlendirilebilir bir araç olmasını olumlu bulmuşlar, kişilerin sosyalleşmesine katkıda bulunması, özgüven ve analitik düşünme becerisini geliştirmesi bakımından güçlü yönlere sahip olduğunu belirtmişlerdir.

Araştırmanın ikinci boyutu esporun olumsuzlukları da denilebilecek zayıf yönleri içermektedir. Katılımcıların bakış açısına dayalı belirlenen zayıf yönler; tanıtım, hukuki problemler, güvenlik problemi, sağlık problemleri, tüketicilerin çabuk sıkılması, kariyer süresi, internet alt yapısı, regülasyon eksikliği ve kötü amaçtır (Tablo 2). Espor gençler arasında çok yaygın olarak bilinse de yaşça büyük kişiler, özellikle ebeveynler için tartışmalı bir konu olmaya devam etmektedir. Ebeveynlerin esporu genellikle zararlı bir alışkanlık ve boşa zaman harcanan aktivite olarak görmesi, ayrıca içerik olarak esporu tam olarak bilmemeleri bu alanda yaşanan önemli sıkıntılardan biridir. Bunun yanı sıra katılımcıların yanıtlarına göre esporun bir diğer zayıf noktası alandaki regülasyon eksikliğidir. Her ne kadar turnuvaları düzenleyen, lisansları veren ve bunlarla ilgili kuralları belirlemeye çalışan yapılar olsa da henüz uluslararası platformda kuralları belirlemesi gereken ve koordinasyon sağlayacak bir federasyon bulunmamaktadır (Abanazir, 2019). Bu durumun yarattığı belirsizlik, esporun bir spor dalı olarak kabul görmesinde dikkate alınması gereken bir zayıflıktır. Araştırmadaki katılımcıların dikkat çektiği bir başka konu espor alanındaki hukuki problemlerdir. Yaşar'a (2018) göre esporun dünyada çok ciddi tartı̧̧malara konu olmakta, doping, şike, bahis, fikri haklar, sporcuların hakları, uyuşmazlıkların çözümü, tahkim yargılaması ve devletin yargı yetkisi, adil yargılanma hakkı gibi konular belirsizlik taşımaktadır. Yasal olarak var olan bu boşlukların espor için oluşturduğu bağlantılı bir sorun da güvenlik problemleridir. Çoğu spor dalında olduğu gibi esporda da bahis oynanmakta fakat oynanan bahislerde "bitcoin" olarak bilinen sanal para kullanılmaktadır. Bunun dışında espor oyun konsolları başında gerçekleştiren bir spor olması sebebiyle uygulama sırasında sporcuların neler yaptığı ya da müsabaka esnasında rekabet ortamını bozacak bir uygulama (hile) kullanılıp kullanılmadığı anında tespit edilememektedir. Tüm bunlar geleneksel sporlar içerisinde bulunan doping, şike gibi spor ruhuyla bağdaşmayan fakat sporun içerisinde bulunan kavramlarla benzerlik gösterirken, esporun zayıf tarafları olarak geleceğini tehdit eden konuların başında gelmektedir.

Espora yönelik alan yazın içerisindeki en büyük eleştiri fiziksel aktivite eksikliğidir. Katılımcılar da bu konuya benzer biçimde yaklaşarak sağlık problemlerini zayıf yön olarak bildirmiştir. Cunnigham ve diğerleri (2018) esporun ne kadar fiziksel aktivite içerdiğinin 
tartışmalı olduğunu söylemektedir. Yine Jenny ve diğerleri (2017) esporun fiziksel aktiviteden yoksun oluşunu eleştirmektedir. Yapılan araştırmalarda esporun bireye sağladığı katkıların yanı sıra bağımlılık, saldırganlık ve sosyal izolasyon gibi zararlı etkilerinin olabileceğine de ayrıca dikkat çekilmektedir (Johansson ve Thilborg, 2010).

Esporun yapısından kaynaklanmamasına karşın esporun geleceğini tehdit eden zayıf yönlerden biri de çağımızın tüketim alışkanlıklarından kaynaklanan sıkılma duygusudur. Günümüzde tüketicilerin herhangi bir ürüne ilgileri oldukça kısa sürmektedir. Bu yüzden pazarlama alanında tüketicilerin ilgilerini kaybetmemesine yönelik yeni stratejiler, yeni ürünler veya var olan ürünlere yönelik yenilemeler yapılmaktadır. Parry (2019) yaptığ1 çalışmada espor modasındaki hızlı değişimin bazı oyunların popülerliğini kaybetmesine ve organizatörlerin gündemde olan oyunların turnuvalarının düzenlemelerine neden olduğunu söylerken, bu hızlı değişen ortamın ticari gelişim, rekabet ortamı ve spor yönetimi konusunda kararlı bir organizasyonel yapının ortaya çıkmasına engel olduğunu belirtmektedir. $\mathrm{Bu}$ görüşler ışığında tüketicilerin sahip olduğu bu sıkılma ve günümüzdeki saf tüketim anlayışının esporun geleceğini tehdit ettiği anlaşılmaktadır.

Araştırmada katılımcıların dikkat çektiği bir konu da profesyonel esporcuların sporu erken yaşta bırakmalarıdır. Espor arenasında sporcuların yaş ortalaması genellikle 24-27 arasında iken aslında geleneksel sporda olduğu gibi teorik bir yaş sınırı bulunmamaktadır (Summerley, 2019). Ancak Hallmann ve Giel (2018) henüz deneysel kantlar olmasa da el-göz koordinasyonu ve hareket hızı ile stratejik ve taktiksel anlayış dahil olmak üzere bazı oyun becerilerinin zamanla kaybolduğuna, yirmili yaşlarının ortalarındaki espor oyuncularının özellikle tepki verme hızları azaldığı için yüksek seviyede rekabet edemediklerini söylemektedir. Erken biten bu spor kariyerleri nedeniyle profesyonel esporcu olmak isteyen kişiler çoğunlukla 15-16 yaşlarından bu camianın içine girerler. Fakat esporun sahip olduğu yoğun tempo bu kişilerin eğitim hayatları gibi hayatlarının diğer alanlarından geri kalmalarına neden olmaktadır. Kişiler üzerindeki bu olumsuz etkinin esporun zayıf yönlerinden biri olduğu anlaşılmaktadır.

Espor ile ilgili göze çarpan bir başka problem ise internet ile ilgilidir. İnternet bugün hayatımızın vazgeçilmezlerinden biri olsa da gelişmiş ülkeler dışında internet fiyatları ve altyapıları oldukça sorunlu, hatta bazı ülkeler için internete erişim sağlamak başlı başına bir sorundur. Gelişmekte olan ülkelerdeki internet altyapısı ve oyunların yayınlanacağı resmi kanalların eksikliğinin espor için bir sınırlılık olduğu belirtilmektedir (Summerley, 2019).

Esporun zayıf yönlerinden sonuncusu kötü amaçtır. Bu kötü amaç kendini kötü amaçlı oyunlarda ve oyunlar ile ilgili dijital platformlardaki linç kültüründe göstermektedir. Video oyunlar çok geniş bir kapsama sahipken, sadece belli bir bölümü espor olarak adlandırılmaktadır. Fakat insanlara maddi ya da manevi olarak zarar verme amaçlı oyunların varlığı (Mavi Balina, Momo vb. gibi) espor alanının imajını zedelemektedir. Ayrıca profesyonel esporcuların herhangi bir performans düşüklüğünde izleyicilerden aldığı aşırı ve kötü içerikli reaksiyon da spor ruhuyla bağdaşmayan bir konudur ve esporun algılanışı açısından olumsuzluklara ve şüphelere yol açmaktadır. 
Sonuç olarak araştırmada yer alan spor yönetimi akademisyenleri ve espor yöneticilerinin bakış açısına dayalı ortaya çıkan güçlü ve zayıf yönlerin, esporun geleceği açısından önemli konular olduğunu söylemek mümkündür. Espor yeni bir alan olmasına karşın yakaladığ 1 büyük gelişme ivmesiyle çoğu geleneksel sporu geride bırakmıştır. Fakat zayıflıkları sebebiyle eksik noktalarının giderilmesine yönelik adımlar atılması gerekmektedir. Belirlenen güçlü ve zayıf yönlerin kendi arasında çatışmalar içerdiği çok açıktır. Örneğin sporculuk anlamında hem kariyer firsatı sunması hem de kariyerin sınırlı olması, kolay ulaşılabilirliğe rağmen internet erişimi ile ilgili olumsuzluklar kendi içinde tezat yaratmaktadır. Yeniye direnç göstermek ya da kuşku ile yaklaşmak insanın doğası gereğidir ancak belki de espor hakkındaki uzun süredir devam eden tartışmaların kaynağı kendisinin yansıttığı çelişkilerdir. Gelecek dijital yerlilerin geleceği olduğu için zamanla bu tartışmaların hız kaybedeceği tahmin edilmektedir.

Çıkar Çatışması: Bu makale ile ilgili yazarlar arasında ve yazarlar ile herhangi bir kurum arasında çıkar çatışması bulunmamaktadır.

Araştırmacıların Katkı Oranı Beyanı: Araştırma Dizaynı- Tunahan Aslan ve Dilşad Çoknaz; Verilerin Toplanması- Tunahan Aslan; Analizler- Tunahan Aslan ve Dilşad Çoknaz; Makalenin hazırlanması- Tunahan Aslan ve Dilşad Çoknaz tarafından gerçekleştirilmiştir.

\section{Etik Kurul İzni ile ilgili Bilgiler}

Kurul Adı: Bolu Abant İzzet Baysal Üniversitesi Sosyal Bilimlerde İnsan Araştırmaları Etik Kurulu

Tarih: 27/12/2018

Sayı/Karar No: 2018/1- Protokol No: 2018/312 
Aslan, T. ve Çoknaz, D. (2021). Güçlü ve zayıf yönleri ile espor: Yönetici ve akademisyen bakış açısına dayalı nitel bir çalışma. Spor Bilimleri Araştırmaları Dergisi, 6(1), 118-136.

\section{KAYNAKLAR}

Abanazir, C. (2019). Institutionalisation in eSports. Sport, Ethics and Philosophy, 13(2), 117-131. DOI: $10.1080 / 17511321.2018 .1453538$

Akgöl, O. (2018). Spor endüstrisi ve dijitalleşme: Türkiye'de espor yapllanması üzerine bir inceleme (Yayınlanmamış Yüksek Lisans Tezi). İstanbul Üniversitesi Sosyal Bilimler Enstitüsü, İstanbul.

Creswell, J.W. (1998). Qualitative inquiry and research design. California:Sage Publications.

Creswell, J.W. (2013). Nitel araştırma yöntemleri: Beş yaklaşıma göre nitel araştırma ve araştırma deseni. Ankara: Siyasal Yayınevi.

Cunningham, G.B., Fairley, S., Ferkins, L., Kerwin, S., Locke, D., Shaw, S. \& Wicker, P. (2018). eSport: Construct specifications and implications for sport management. Sport Management Review, 21(1), 1-6. DOI:10.1016/j.smr.2017.11.002

Demirkol, O. (2019, 20 Haziran). Broken Blade, TSM'e transfer oldu. Erişim adresi: http://www.5mid.com/lol/broken-blade-tsm-transfer-oldu.

Funk, D.C., Pizzo, A.D. \& Baker, B.J. (2018). eSport management: Embracing eSport education and research opportunities. Sport Management Review, 21(1), 7-13. DOI: 10.1016/j.smr.2017.07.008.

Newzoo. (2018). Global esports market report. Erişim adresi: https://newzoo.com/insights/trend-reports/globalesports-market-report-2018-light/

Newzoo. (2020). Global esports market report. Erişim adresi: https://newzoo.com/insights/trendreports/newzoo-global-esports-market-report-2020-light-version/

Hallmann, K. \& Giel, T. (2018). eSports-Competitive sports or recreational activity. Sport Management Review, 21(1), 14-20. DOI: 10.1016/j.smr.2017.07.011

Hamari, J. \& Sjöblom, M. (2017). What is esports and why do people watch it? Internet Research, 27 (2), 211 232. DOI: $10.1108 /$ IntR-04-2016-0085

Heere, B. (2018). Embracing the sportification of society: Defining e-sports through a polymorphic view on sport. Sport Management Review, 21(1), 21-24. DOI: 10.1016/j.smr.2017.07.002

Jenny, S.E., Manning, R.D., Keiper, M.C. \& Olrich, T.W. (2017). Virtual(ly) athletes: Where eSports Fit Within the Definition of "Sport?. Quest, 69 (1), 1-18. DOI: 10.1080/00336297.2016.1144517

Johansson, K. \& Thilborg, J. (2010). Electronic sport and its impact on future sport, Sport in Society, 13(2), 287299. DOI: $10.1080 / 17430430903522996$

Karahan, T. (2019). Cloud9 Microsoft ile Espor Teknolojileri Üretecek. Erişim adresi: https://esporhit.com.tr/cloud9-microsoft-espor-teknolojileri-ortakligi/

Kozachuk, J., Foroughi, C.K. \& Freeman, G. (2016). Exploring electronic sports: An interdisciplinary approach. Proceedings of the Human Factors and Ergonomics Society, 60(1), 2118-2122. DOI: $10.1177 / 1541931213601479$

Miles, M.B. \& Huberman, A.M. (1994). Qualitative data analysis: An expanded sourcebook. Californi: SAGE Publications. 
Aslan, T. ve Çoknaz, D. (2021). Güçlü ve zayıf yönleri ile espor: Yönetici ve akademisyen bakış açısına dayalı nitel bir çalışma. Spor Bilimleri Araştırmaları Dergisi, 6(1), 118-136.

Ntv.com.tr. (2016, 10 Ekim) Türkiye CS: GO 2016 Dünya Şampiyonu oldu. Erişim adresi:https://www.ntv.com.tr/teknoloji/turkiye-cs-go-2016-dunya-sampiyonuoldu,VjwC04ViOEKDexwgZ4Abrg

Ntv.com.tr. (2014, 2 Nisan) Türkiye'nin ilk lisanslı LOL Espor Turnuvası sona erdi. Erişim adresi: https://www.ntv.com.tr/turkiye/turkiyenin-ilk-lisansli-lol-espor-turnuvasi-sonaerdi cSwOel53ykiIOIBMkHBFhg

Özbıçakçı, S.T. (2016). Esports: Alternative fandom research in Turkey (Yayınlanmamış Yüksek Lisans Tezi). Bilkent Universitesi, Ankara.

Özenç, O. E. ve Tinmazlar, A. (2019). Dijital oyunlar serisi 3: Türkiye'de espor ve League of Legends (3.Baskı). İstanbul: Profil Kitap.

Parry, J. (2019). E-sports are not sport. Sport, Ethics and Philosophy, 13(1), 3-18. DOI: $10.1080 / 17511321.2018 .1489419$

Patton, M.Q. (1990). Qualitative evaluation and research methods. California: Sage Publications.

Patton, M.Q. (2002). Qualitative research \& evaluation methods. Thousand Oaks, CA: Sage Publications.

Prensky, M. (2001). Digital natives, digital immigrants. On the Horizon, 9(5), 1-5.

Summerley, R. (2019). The development of sports: A comparative analysis of the early institutionalization of traditional sports and e-sports. Games and Culture, 15(1), 51-72. DOI: 10.1177/1555412019838094

Tarakçı E. (2020) Esporun Lokomotifleri I: Dark Passage Espor (2021, 26 Mart). Erişim adresi: https://esportimes.com/tr/milli-gururlarimizdan-dark-passage-espor-kulubunu-kisaca-taniyalim/.

Türsen, D. (2017). eSpor'da kariyer var. Erişim adresi: http://www.hurriyet.com.tr/ik-yeniekonomi/espor-dakariyer-var-29079553.

Yaşar, M. (2018). Türkiye E-spor Federasyonu İki Talimat Yayınladı. Erişim adresi: https://sporvehukuk.net/tag/e-sporcu/

Yıldırım, A. ve Şimşek, H. (2013). Sosyal bilimlerde nitel araştırma yöntemleri (9. Baskı). Ankara: Seçkin.

Wagner, M.G. (2006). On the scientific relevance of esports. International Conference on Internet Computing Conference Paper. Erişim adresi: https://www.semanticscholar.org/paper/On-the-Scientific-Relevanceof-eSports-Wagner/5be4a1125a6c473259183698109e301c6c5309cd.

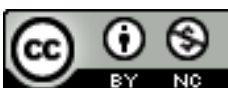

Bu eser Creative Commons Atıf-Gayri Ticari 4.0 Uluslararası Lisansı ile lisanslanmıștır. 